\title{
PERSEPSI MASYARAKAT TERHADAP UPAYA PENGEMBANGAN DESA WISATA JERUK PAMELO ORGANIK DI DESA TAMBAKMAS, KECAMATAN SUKOMORO, KABUPATEN MAGETAN
}

\author{
Sri Wiyatiningsih" ${ }^{1)}$, Wiwik Sri Harijani' ${ }^{2)}$, Wahyu Santoso ${ }^{3)}$, Riko Setya Wijaya ${ }^{4)}$ \\ 1,2,3,4 Universitas Pembangunan Nasional "Veteran" Jawa Timur \\ Jalan Raya Rungkut Madya Gunung Anyar, Surabaya \\ E-mail: ${ }^{3}$ wahyu.agri@upnjatim.ac.id
}

\begin{abstract}
Abstrak
Pengembangan tanaman jeruk pamelo di Desa Tambakmas memiliki dua sisi kontradiktif, terdapat kendala seperti halnya rendahnya tingkat produktivitas dan kualitas buah, perilaku petani dalam penggunaan pestisida kimia dan jalur pemasaran dikuasai pengepul, sedangkan potensi desa dengan jumlah penduduk dan sumber daya alam pendukungnya menjadi peluang untuk dimanfaatkan melalui usulan skim hibah Program Pemberdayaan Masyarakat Unggulan Perguruan Tinggi (PPMUPT). Pengabdian masyarakat ini dilakukan bermaksud untuk mengidentifikasi persepsi masyarakat dalam pengembangan Desa Wisata Jeruk Pamelo Organik berbasis Biopestisida. Informasi data yang berhasil dikumpulkan dari sebaran kuesioner selanjutnya diproses dengan pendekatan statistik deskriptif kualitatif dan penyajiannya didukung oleh software MS. Excel 2013 dan IBM SPSS Ver. 23. Hasil pelaksanaan pengabdian masyarakat Persepsi internal berhasil terbentuk dari masyarakat yang berpartisipasi dalam pengembangan desa wisata jeruk pamelo organik adalah mereka telah berumur 40 tahun dan atau lebih, berjenjang pendidikan terbanyak adalah SLTA atau sederajat serta memiliki motivasi pokok yaitu meningkatkan pendapatan sambil tetap mempertahankan produktivitas jeruk pamelo yang dibudidayakannya. Eksistensi pengembangan desa wisata jeruk pamelo organik dipersepsikan secara baik pada indikator dukungan kelompok tani dan dukungan Tim PPMUPT. Sebaliknya, indikator dukungan pemerintah desa dipersepsikan biasa saja, karena mereka mengganggap dukungan pemerintah baik desa maupun kabupaten belum sepenuhnya memenuhi harapan masyarakat.
\end{abstract}

Kata Kunci: Jeruk Pamelo, Pertanian Organik, Desa Wisata, dan Persepsi.

\begin{abstract}
Pamelo orange development in Tambakmas Village has two contradictory sides, there are obstacles such as the low level of productivity and quality of fruit, the behavior of farmers in the use of chemical pesticides and marketing channels controlled by collectors, while the potential of villages with population and supporting natural resources is an opportunity to be utilized through the proposed scheme of Higher Education Community Empowerment Program (PPMUPT). This community service is intended to identify community perceptions in the development of Biopesticide-based Organic Jerelo Pamelo Tourism Village. Information data that was collected from the distribution of the questionnaire was then processed using a qualitative descriptive
\end{abstract}


statistical approach and its presentation was supported by MS software. Excel 2013 and IBM SPSS Ver. 23. The results of the implementation of community service Internal perception has been formed from the community who participated in the development of the organic tourist village orange Pamelo is that they have aged 40 years or more, most education levels are high school or equivalent and have the main motivation that is increasing income while still maintaining orange productivity the pamelo he cultivated. The existence of the development of organic Pamelo orange tourism village is well perceived in the indicators of farmer group support and the support of the PPMUPT Team. On the contrary, the indicators of village government support are perceived to be ordinary, because they assume government support both village and district has not fully met the expectations of the community.

Keywords: Pamelo Oranges, Organic Agriculture, Tourism Villages, and Perception.

\section{PENDAHULUAN}

Sebuah potret kehidupan di perdesaan selalu dikaitkan dengan kebersahajaan, keterbelakangan, tradisionalisme, subsistensi, dan keterisolasian. Masyarakat desa dipandang memiliki tingkat kesejahteraan yang rendah. Banyak desa yang diklaim masih menjadi Desa Berkembang secara agregat di Indonesia adalah sebanyak 55.369 desa atau sebesar 73,40 \% (PODES, 2018). Mencermati lebih jauh desa-desa berstatus berkembang tetapi dihandalkan untuk sektor pertaniannya terkendala pada produktivitas, efisiensi usaha sampai dengan konservasi lahan.

Permasalahan umum dijumpai pada Desa Tambakmas, Kecamatan Sukomoro, Kabupaten Magetan sebagai daerah sentra produksi Jeruk pamelo. Pengembangan tanaman jeruk pamelo diwarnai dengan beberapa masalah diantaranya 1) rendahnya tingkat produktivitas dan kualitas buah. Hal ini disebabkan sebagian besar budidaya jeruk pamelo masih dilakukan secara konvensional dan bersifat alternate bearing yaitu berbuah banyak pada satu musim dan berbuah sedikit pada musim berikutnya. Charina, Rani dan Yosini (2018) mengungkapkan rendahnya produksi lebih disebabkan pada cara budidaya yang kurang maksimal. Bibit yang bermutu dan berkualitas merupakan langkah pertama yang penting dalam keberhasilan budidaya. Sedangkan masalah pada kualitas buah, dimana terjadi kerusakan yang disebabkan adanya serangan hama dan penyakit seperti lalat buah dan penyakit bintil-bintil pada lapisan kulit jeruk dan untuk meminimalkan kerugian petani melakukan panen dini buah. Adapun identifikasi dilapang menunjukkan bahwa serangan hama dan penyakit terdiri dari Lalat buah, Puru buah, dan Diplodia atau Blendok.

Permasalahan kedua (2) yaitu perilaku petani dalam penggunaan pestisida kimia dan jalur pemasaran dikuasai pengepul. Penggunaan pestisida dalam mengatasi organisme pengganggu tanaman telah membudaya dikalangan petani jeruk pamelo Desa Tambak Mas. Penggunaan pestisida yang dilakukan oleh petani jeruk pamelo umumnya tidak lagi mengindahkan aturan dosis yang dianjurkan hanya untuk mengejar panen lebih cepat sehingga memperoleh keuntungan. Selain itu, petani jeruk pamelo Desa Tambak Mas, Kecamatan Sukomoro, Kabupaten Magetan, masih kesulitan memasarkan sendiri hasil panennya. Hingga saat ini, pemasaran pamelo masih dilakukan 
oleh pedagang pengepul lokal secara perorangan. Biasanya buah jeruk yang sudah siap panen langsung dibeli dengan harga yang disepakati kedua oleh pihak atau disebut dengan sistem 'tebasan' dan bahkan jeruk pamelo dijual sejak masih berbentuk bunga sehingga harga jual jeruk di tingkat petani jauh lebih murah dibanding harga jual di tingkat konsumen.

Lain sisi, dengan luas wilayah Desa Tambak Mas sebesar 250,12 ha, yang terbagi menjadi tanah sawah seluas 151,43 Ha, bukan sawah seluas 63,16 $\mathrm{Ha}$ dan penggunaan tanah lainnya seluas 35,53 $\mathrm{Ha}$ (BPS. Kab. Magetan, 2018) perlu disepakati bahwa keberlanjutan sistem pertanian desa harus dipertahankan. Penduduk merupakan potensi sumber daya manusia suatu daerah, dalam kaitannya dengan faktor tenaga kerja. Komposisi penduduk berdasarkan umur di Desa Tambak Mas sebagian besar tergolong dalam usia produktif (15-59 tahun) yaitu sebanyak 1236 orang. Penduduk yang tergolong dalam usia non produktif (0-14 tahun dan > 60 tahun) adalah sebesar 365 orang dan 321 orang. Menurut Mantra (2009), penduduk umur 0-14 tahun dianggap sebagai kelompok penduduk belum produktif, kelompok penduduk umur 15-64 tahun sebagai kelompok produktif dan kelompok umur 65 tahun ke atas sebagai kelompok penduduk yang tidak lagi produktif.

Pemahaman logis antara permasalahan yang dihadapi dengan kekuatan yang dimiliki maka seyogyanya menuntut langkah konkrit untuk diselaraskan. Salah satu alternatif program yang dapat memenuhi kebutuhan masyarakat khususnya secara ekonomi namun program tersebut juga turut menjaga ekosistem kawasan adalah pengembangan desa wisata. Lane dan Kastenholz, 2015; Avenzora dan Teguh, 2013) sepaham untuk menyatakan pengembangan desa wisata dapat meningkatkan nilai tambah suatu kawasan melalui jasa wisata dan pemasaran produk pertanian yang lebih baik, sehingga dapat memandirikan dan memajukan perekonomian setempat terutama petani.

Desa wisata adalah kawasan pedesaan yang menampilkan berbagai macam atraksi wisata yang dikemas sedemikian rupa sehingga dapat menarik wisatawan untuk berkunjung dan menetap, menghabiskan waktu berhari-hari, mengenal lebih dekat budaya desa, dan melakukan aktivitas yang dilakukan masyarakat desa (Lane dan Kastenholz, 2015). Pariwisata pedesaan menurut (Wang \& Pfister, 2008; Williams \& Lawson, 2001) dapat dilihat sebagai suatu pemukiman dengan fasilitas lingkungan yang sesuai dengan tuntutan wisatawan dalam menikmati, mengenal, dan menghayati kekhasan desa dengan segala daya tariknya dan tuntutan kegiatan hidup bermasyarakat.

Mendukung percepatan tercapainya program tersebut, maka melalui skema hibah Program Pemberdayaan Masyarakat Unggulan Perguruan Tinggi (PPMUPT) telah dirancang sebuah konsep "Pengembangan Desa Wisata Pamelo Organik Berbasis Biopestisida" dengan tujuan memberdayakan masyarakat Desa Tambak Mas Kecamatan Sukomoro Kabupaten Magetan sehingga mampu melaksanakan pengendalian penyakit yang aman, ramah lingkungan dan terpadu dengan memanfaatkan teknologi yang potensial dari hasil riset dan pengembangan LPPM UPN "Veteran" Jatim yaitu Biopestisida Peningkat Ketahanan Tanaman sekaligus sebagai solusi permasalahan masyarakat yang menginginkan peningkatan perekonomian serta pengetahuan dan ketrampilan masyarakat untuk mengelola desa wisata.

Ciri khas pengelolaan desa wisata dengan destinasi wisata lainnya yaitu bersifat partisipatif dari masyarakat setempat. Hasil 
penelitian Gao dan Bihu (2017); Xu, Xingyu dan Qianfan (2018); menyimpulkan bahwa keberadaaan desa wisata sangat berpengaruh pada peningkatan kesejahteraan masyarakat baik ekonomi, pembentukan komunitas masyarakat, pendidikan dan ketahanan ekologi/lingkungan (Pratt, Scott, Apisalome, 2016) dengan dukungan partisipasi masyarakat. Oleh karena itu, perlu mencermati persepsi masyarakat sebagai kunci pelaksana kegiatan desa wisata. Persepsi masyarakat yang tidak benar mengenai desa wisata akan menghasilkan dampak negatif bagi keberlangsungan, dan sebaliknya apabila pengembangan desa wisata di persepsi secara baik maka menghasilkan dampak positif bagi pengembangan desa wisata yang telah direncanakan.

Adapun penyusunan artikel dilakukan bermaksud untuk mengidentifikasi persepsi masyarakat dalam pengembangan Desa Wisata Jeruk Pamelo Organik berbasis Biopestisida baik yang berasal dari internal maupun divisualisasikan secara eksternal lingkungannya.

\section{METODE PELAKSANAAN}

\section{Lokasi dan Prosedur Program}

Pelaksanaan pengabdian PPMUPT ini secara sengaja (purposive) ditetapkan kepada kedua kelompok tani yaitu Sekar Mulyo dan Sumber Mas di Kecamatan Sukomoro, Kabupaten Magetan dengan mempertimbangkan potensi produksi jeruk pamelo terbanyak dan aktif melaksanakan kegiatan bersifat kelompok. Adapun pelaksanaan program PPMUPT terdiri dari dua (2) kegiatan utama yaitu a) Pemberdayaan masyarakat petani melalui pelatihan tentang cara pengendalian penyakit pada tanaman jeruk pamelo. Pelatihan pengendalian dengan pendekatan pemberdaan masyarakat sehingga mampu melaksanakan pengendalian penyakit yang aman, ramah lingkungan dan terpadu melalui Formula Biopestisida berbasis Mikroorganisme atau dikenal dengan nama FOBIO. FOBIO sudah mendapatkan nomor pendaftaran HKI P00201200183, nomor pendaftaran Hak Cipta Merk dan Logo nomor D002017044370, serta Sertifikat ISO 9001:2015 dari ASACERT UK Ltd. untuk Production of Biopesticide Formulation (FOBIO) Based on Microorganism. b) Penyuluhan tentang pentingnya Upaya Pengembangan Desa Wisata Pamelo Organik. Desa Wisata Pamelo Organik merupakan penciptaan kelompok swadaya dan swakarsa masyarakat yang dalam hal ini aktivitas sosialnya berupaya untuk meningkatkan pemahaman kepariwisataan melalui pertanian jeruk pamelo organik, mewadahi peran dan partisipasi masyarakat petani jeruk pamelo dalam pembangunan kepariwisataan di wilayahnya, meningkatkan nilai kepariwisataan sehingga pada akhirnya mampu meningkatkan pendapatan ekonomi masyarakat.

\section{Persiapan}

Tahap awal Pengembangan Desa Wisata Jeruk Pamelo Organik berbasis Biopestisida oleh tim pelaksana PPMUPT dilakukan dengan meminta izin sekaligus arahan kepada Bupati Magetan, kemudian dilanjutkan dengan koordinasi antara tim pelaksana PPMUPT dengan pihak Dinas Pertanian dan Ketahahan Pangan Kabupaten Magetan, Pemerintah Desa Tambakmas, Kecamatan Sukomoro, Kabupaten Magetan, serta kelompok tani Sekar Mulyo dan Sumber Mas sebagai sebagai mitra program PPMUPT. Persiapan meliputi sosialisasi program, diskusi strategi realisasi program, koordinasi penyiapan kegiatan, serta aspek teknis lainnya. 
Tabel 1. Rencana Aksi Pelaksanaan Program PPMUPT

\begin{tabular}{|c|c|c|c|c|c|c|c|c|c|c|c|c|c|}
\hline \multirow{2}{*}{ No } & \multirow{2}{*}{ Nama Kegiatan } & \multicolumn{12}{|c|}{ Bulan } \\
\hline & & 1 & 2 & 3 & 4 & 5 & 6 & 7 & 8 & 9 & 10 & 11 & 12 \\
\hline 1 & Persiapan & & & & & & & & & & & & \\
\hline 2 & $\begin{array}{l}\text { Penyuluhan tentang pentingnya Upaya } \\
\text { Pengembangan Desa Wisata Pamelo } \\
\text { Organik }\end{array}$ & & & & & & & & & & & & \\
\hline 3 & $\begin{array}{l}\text { Pemberdayaan masyarakat petani melalui } \\
\text { pelatihan tentang cara pengendalian } \\
\text { penyakit pada tanaman jeruk pamelo } \\
\text { berbasis Fobio }\end{array}$ & & & & & & & & & & & & \\
\hline 4 & Persiapan Pembuatan Demplot & & & & & & & & & & & & \\
\hline 5 & $\begin{array}{l}\text { Pembuatan demplot pengendalian } \\
\text { penyakit tanaman jeruk pamelo berbasis } \\
\text { Fobio dan penyusunan SOP nya }\end{array}$ & & & & & & & & & & & & \\
\hline 6 & Publikasi ke Media Masa & & & & & & & & & & & & \\
\hline 7 & $\begin{array}{l}\text { Penyiapan draft publikasi \& submit jurnal, } \\
\text { HKI, buku ajar }\end{array}$ & & & & & & & & & & & & \\
\hline 8 & Pengumpulan Laporan Akhir & & & & & & & & & & & & \\
\hline
\end{tabular}

\section{Waktu Pelaksanaan}

Sesuai dengan target luaran yang telah ditetapkan, maka rencana tahapan kegiatan PPMUPT selama tahun 2019 sebagaimana disajikan pada Tabel 1. Penetapan waktu tersebut merupakan rancangan kegiatan yang akan dilaksanakan oleh tim pelaksana PPMUPT terhitung sejak tanda tangan kontrak bersama Lembaga Penelitian dan Pengabdian kepada Masyarakat (LPPM) Universitas Pembangunan Nasional (UPN) "Veteran" Jawa Timur.

\section{Instrumen dan Interpretasi Data}

Instrumen yang digunakan dalam program pengabdian PPMUPT adalah melalui diskusi mendalam dengan mitra program, observasi Tim PPMUPT secara langsung di lapangan, serta penyebaran kuesioner. Persepsi masyarakat yang dianalisis mencakup persepsi internal dan persepsi eksternal. Faktor internal adalah faktor yang berasal dari dalam diri seorang individu yang mencakup karakteristik individu sehingga memengaruhi individu dalam berpartisipasi dalam kegiatan pengembangan desa wisata jeruk pamelo organik. Faktor internal yaitu mencakup usia, tingkat pendidikan, serta motivasi individu dalam berpartisipasi. Persepsi masyarakat mengenai faktor eksternal merupakan faktor yang memengaruhi partisipasi masyarakat dalam pengembangan desa wisata yang berasal dari luar atau lingkungan individu. Radjabaycolle dan Sumardjo (2014) menyatakan bahwa faktor-faktor eksternal terdiri dari dukungan tokoh masyarakat, dukungan masyarakat sekitar, tingkat ketersediaan fasilitas, dan sumber informasi, kemudian diadopsi menjadi tiga faktor eksternal utama yaitu dukungan kelompok masyarakat, dukungan pemerintah, serta dukungan sarana dan prasarana (fasilitas).

Data yang dihasilkan dari sebaran kuesioner dikelompokkan berdasarkan variabel-variabel yang sebelumnya telah diberi skoring dan pengkategorian dengan teknik Deskriptif Kualitatif. Analisis deskriptif kualitatif disajikan dalam bentuk tabel baik angka mutlak maupun persentase. Untuk menghitung hasil persentase tersebut dengan rumus sebagai berikut: 


$$
\mathrm{P}=\frac{f}{N} \times 100 \%
$$

Dimana:

$\mathrm{P}=$ Persentase

$\mathrm{f}$ = frekuensi masing-masing jawaban

$\mathrm{N}$ = Jumlah Responden

Pengukuran setiap item jawaban dihubungkan dengan bentuk pernyataan atau dukungan sikap yang diungkapkan dengan kata-kata sebagai berikut:

$\begin{array}{ll}\text { Sangat Setuju } & =5 \\ \text { Setuju } & =4 \\ \text { Netral } & =3 \\ \text { Tidak Setuju } & =2 \\ \text { Sangat Tidak Setuju } & =1\end{array}$

Selanjutnya data tersebut diolah menggunakan aplikasi Microsoft Excel 2013 dan IBM SPSS Statistics Ver. 23 kemudian dibahas sehingga diperoleh informasi menyeluruh terkait persepsi masyarakat adanya program PPMUPT.

\section{HASIL DAN PEMBAHASAN}

\section{Persepsi Internal dalam Pengembangan Desa Wisata Jeruk Pamelo Organik}

Persepsi (perception) dalam arti sempit adalah penglihatan, bagaimana cara seseorang melihat sesuatu, sedangkan dalam arti luas adalah pandangan atau pengertian atau penilaian yaitu bagaimana seseorang memandang atau mengartikan sesuatu, persepsi juga termasuk proses komunikasi yang timbul karena adanya respon terhadap stimulus dimana destinasi wisata dibentuk (Williams \& Lawson, 2001). Xua, Xingyu dan Qianfan (2018) mengemukakan bahwa karakteristik seseorang merupakan salah satu faktor yang dapat mempengaruhi persepsi seseorang. Keragaman persepsi faktor personal berupa umur, pendidikan, pengetahuan, dan pengalaman.

Berdasarkan hasil persepsi internal yang tampak pada gambar 1., memperlihatkan bahwa usia responden terbanyak adalah pada kelompok usia $>40$ tahun. Usia merupakan salah satu faktor yang dapat mempengaruhi kemampuan fisik dan respon terhadap hal - hal baru dalam menjalankan usaha desa wisata (Xua, Xingyu dan Qianfan, 2018). Selain itu, usia dapat menentukan cara mengadopsi inovasi baru. Semakin tua usia kadangkala seseorang merasa lebih kaya pengalaman dibandingkan dengan yang berusia jauh lebih muda.

Oleh karenanya bekal pengalaman tersebut menjadikan seseorang lebih bijaksana dalam bertindak, menentukan langkah sampai dengan pengambilan sebuah keputusan terutama ikut serta dalam pengembangan desa wisate jeruk pamelo organik. Pendidikan merupakan faktor penting terhadap kemampuan bekerja, karena dengan pendidikan yang dimiliknya dapat mempengaruhi tingkat pengetahuan, cara berfikir dan ketrampilannya. Berdasarkan Gambar 1. dapat diketahui bahwa dari sebanyak 30 orang responden, sebagian besar responden dalam penelitian ini memiliki pendidikan terakhir SLTA atau sederajat sebanyak orang 19 orang sedangkan sisanya masing-masing sebanyak 10 orang adalah tamatan pendidikan SLTP dan 1 orang adalah tamatan SD. Rakhmat (1998), berpendapat bahwa perbedaan tingkat pendidikan akan menghasilkan persepsi yang berbeda pula pada suatu obyek atau peristiwa. Semakin tinggi jenjang pendidikan diharapkan mampu membentuk persepsi yang baik dan terbuka dalam upaya pengembangan desa wisata jeruk pamelo organik. 


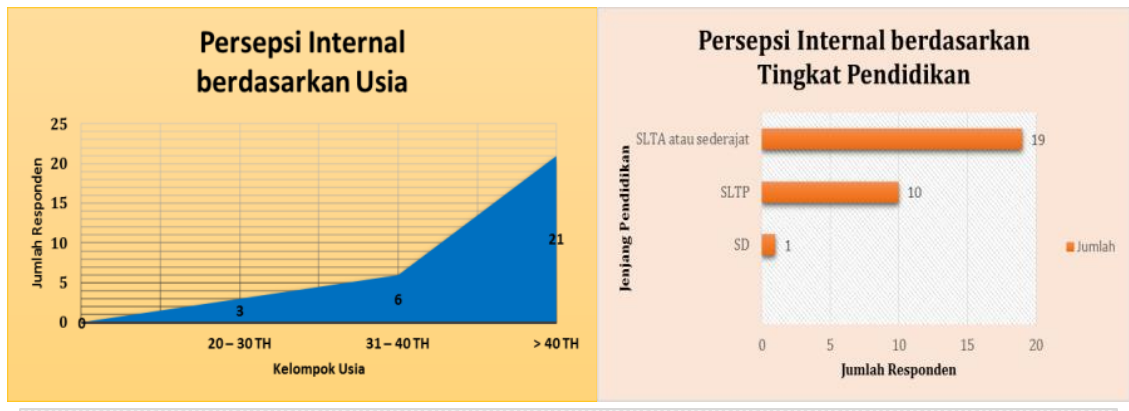

\section{Persepsi Internal berdasarkan Motivasi Berpartisipasi dalam Pengembangan Desa Wisata}

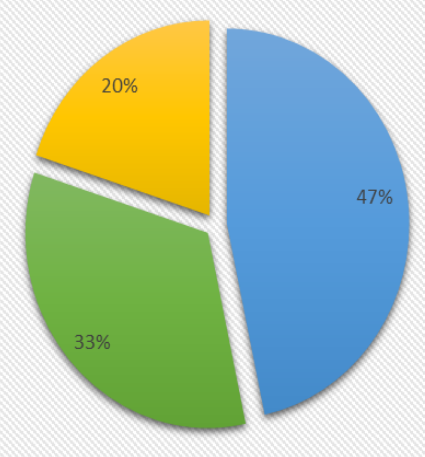

Memperoleh Peningkatan Pendapatan

Meningkatkan Produktivitas Tanaman Jeruk Pamelo

- Mempromosikan Kultur Sosial Desa dan Mempertahankan Hubungan Kemasyarakatan

\section{Gambar 1. Berbagai Hasil Persepsi Internal dalam Pengembangan Desa Wisata Jeruk Pamelo Organik}

Sumber : Hasil Analisis (2019)

Hasil lainnya menunjukkan bahwa motivasi responden berpartisipasi dalam pengembangan desa wisata jeruk pamelo organik lebih disebabkan oleh keinginan masyarakat untuk meningkatkan pendapatan rumah tangganya (47\%). Keberadaan desa wisata jeruk pamelo ini memiliki harapan menjadi daya ungkit perekonomian masyarakat terutama bagi mereka yang sebagian besar mengandalkan kehidupan sehari-harinya yaitu budidaya jeruk pamelo tanpa adanya usaha sampingan. Informasi spesifik diperoleh adalah sebanyak (33\%) responden menyatakan motivasi ikut program pengembangan desa wisata organik karena mereka menginginkan adanya peningkatan produksi jeruk pamelo yang diusahakannya. Selama ini yang terjadi adalah tanaman jeruk pamelo yang dibudidayakan selalu mengalami kerugian akibat serangan hama dan penyakit terdiri dari Lalat buah, Puru buah, dan Diplodia atau Blendok. Sedangkan $20 \%$ responden menjawab motivasi untuk ikut program desa wisata dikarenakan keinginan untuk mempromosikan kultur sosial desa dan mempertahankan hubungan kemasyarakatan.

Masyarakat menggangap di era digital seperti saat ini menjaga identitas lingkungan desa adalah penting dilakukan, terlebih menjaga hubungan antar masyarakat yang ada seperti gotong royong, tradisi bersih desa dan bahkan terdapat budaya khas Desa Tambakmas yang dikenal dengan istilah "Brokohan" tradisi ini di lengkapi dengan tumpeng yang memiliki filosofi yaitu 
tumpeng yang di gunakan berbentuk kerucut sebagai lambang keagungan gunung lauk pauk merupakan rasa syukur atas karunia hasil bumi.

\section{Persepsi Eksternal dalam}

\section{Pengembangan Desa Wisata Jeruk Pamelo Organik}

Pengembangan desa wisata jeruk pamelo Desa Tambakmas merupakan kolaborasi aktif dari semua kalangan mulai dari kelompok petani, swasta, pemerintah desa hingga pemerintah Kabupaten Magetan yang selaras dengan program TIM PPMUPT. Dukungan yang diberikan bisa berupa tenaga, pikiran, materi dan hal lainnya seperti pemantauan pelaksanaan kegiatan wisata, aktif mengajak masyarakat untuk berpartisipasi, menyelenggarakan pelatihan, hingga pemberian fasilitas pendukung kegiatan wisata mulai dari lahan parkir, pusat informasi, infrastruktur fisik dan lain sebagainya. Namun dalam keadaan di lapangan pemberian dukungan tersebut dirasakan berbeda oleh responden, oleh karena perlu digali informasi persepsi terhadap pengembangan desa wisata jeruk pamelo organik. Adapun indikator variabel yang diamati ditunjukkan pada Tabel 2 . sedangkan hasil analisis tampak pada Tabel 3.

Tabel 2. Instrumen Data Persepsi Pengembangan Desa Wisata Jeruk Pamelo Organik

\begin{tabular}{|c|c|}
\hline Indikator & Pernyataan Persepsi \\
\hline \multirow{5}{*}{$\begin{array}{l}\text { Dukungan } \\
\text { Kelompok Tani }\end{array}$} & 1) Aktif Mengajak Partisipasi Mengelola DesaWisata \\
\hline & 2) Menetapkan Tujuan secara Jelas dalam Mengelola Desa Wisata \\
\hline & 3) Mencari Inovasi dalam Mengelola Desa Wisata \\
\hline & $\begin{array}{l}\text { 4) Menjalin Kerjasama_dengan Kelompok Masyarakat Lainnya (seperti: PEL, Karang Taruna, } \\
\text { Kelompok Ibu-Ibu dsb) }\end{array}$ \\
\hline & 5) $\quad$ Mengadakan Pertemuan Kelompok secara Rutin \\
\hline \multirow{5}{*}{$\begin{array}{c}\text { Dukungan } \\
\text { Pemerintah }\end{array}$} & 1) $\quad$ Aktif Membentuk Kelompok Sadar Wisata (POKDARWIS) \\
\hline & 2) $\quad$ Menyelenggarakan Pelatihan Ketrampilan untuk masyarakat desa \\
\hline & $\begin{array}{l}\text { 3) Mendukung Sarana dan Prasarana mendukung Budidaya Jeruk Pamelo Organik (misal: Jalan } \\
\text { Usaha Tani/JUT, Sumur air, } \quad \text { Bibit dsb) }\end{array}$ \\
\hline & $\begin{array}{l}\text { 4) Mendukung Fasilitas Wisata (misal: lahan parkir, petunjuk arah, unit pengelola olahan jeruk } \\
\text { pamelo, tempat kuliner dsb) }\end{array}$ \\
\hline & 5) Menetapkan Anggaran Desa/Kabupaten untuk Desa Wisata \\
\hline \multirow{5}{*}{$\begin{array}{l}\text { Dukungan } \\
\text { Tim PPMUPT }\end{array}$} & 1) Mendampingi Paket Budidaya Jeruk Pamelo Berbasis FOBIO \\
\hline & 2) $\quad$ Memfasilitasi Pengajuan Sertifikat Organik \\
\hline & Meningkatkan Ketrampilan Manajemen Desa Wisata \\
\hline & Menginisiasi Terwujudnya Kelembagaan DesaWisata \\
\hline & Monitoring Keberlanjutan Program Desa Wisata \\
\hline
\end{tabular}

Sumber : Instrumen Data (2019). 
Tabel 3. Hasil Analisis Persepsi Pengembangan Desa Wisata Jeruk Pamelo Organik Descriptive Statistics

\begin{tabular}{|c|c|c|c|c|c|}
\hline & $\mathrm{N}$ & Minimum & Maximum & Mean & $\begin{array}{c}\text { Std. } \\
\text { Deviation }\end{array}$ \\
\hline Aktif_Mengajak_PartisipasiDesaWisata & 30 & 2 & 5 & 3.80 & .847 \\
\hline Menetapkan_TujuanJelas_dlm_MengelolaDesaWisata & 30 & 2 & 5 & 3.53 & .681 \\
\hline Mencari_Inovasi_MengelolaDesa Wisata & 30 & 1 & 5 & 3.20 & .925 \\
\hline Menjalin_Kerjasama_dgn_Kelompok MasyarakatLainnya & 30 & 2 & 5 & 3.80 & .610 \\
\hline Merngadakan_PertemuanRutinKelompok & 30 & 2 & 4 & 3.30 & .535 \\
\hline Aktif_Membentuk_Pokdarwis & 30 & 2 & 5 & 3.47 & .681 \\
\hline Menyelenggarakan_Pelatihan Ketrampilan & 30 & 1 & 4 & 2.93 & 1.015 \\
\hline Mendukung_Saprodi_BudidayaJeruk PameloOrganik & 30 & 1 & 4 & 3.23 & .626 \\
\hline Mendukung_FasilitasWisata & 30 & 1 & 5 & 2.10 & .923 \\
\hline Menetapkan_AnggaranDesa/Kabupaten_untukDesa Wisata & 30 & 1 & 4 & 1.90 & .845 \\
\hline Mendampingi_PaketBudidaya_BerbasisFOBIO & 30 & 2 & 5 & 3.93 & .740 \\
\hline Memfasilitasi_PengajuanSertifikatOrganik & 30 & 2 & 5 & 4.00 & .695 \\
\hline Meningkatkan_Ketrampilan_ManajemenDesaWisata & 30 & 1 & 5 & 3.57 & .898 \\
\hline Menginisiasi_Terwujudnya_KelembagaanDesaWisata & 30 & 2 & 5 & 3.53 & .730 \\
\hline Monitoring_Keberlanjutan_ProgramDesa Wisata & 30 & 2 & 5 & 3.63 & .999 \\
\hline Valid N (listwise) & 30 & & & & \\
\hline
\end{tabular}

Sumber : Data Diolah (2019).

Kategori Rata-rata Skor Persepsi :

1-1,80 Sangat Buruk

1,80-2,60 Buruk

2,60-3,40 Biasa Saja

3,40-4,20 Baik

4,20-5 Sangat Baik

\section{a) Dukungan Kelompok Tani}

Kelompok tani dalam program PPMUPT merupakan sasaran utama dari pelaksanaan pengabdian masyarakat yang dilakukan. Kelompok tani sebagai mitra program telah ditetapkan adalah Poktan Sekar Mulyo dan Poktan Sumber Mas yang ada di Desa Tambak Mas, Kecamatan Sukomoro, Kabupaten Magetan. Nilai rataan skor yang tertinggi sebesar 3,80 merujuk pada pernyataan "Aktif Mengajak Partisipasi Mengelola Desa Wisata" dan "Menjalin Kerjasama dengan Kelompok Masyarakat Lainnya". Hasil ini memberikan gambaran bahwa dukungan kelompok tani dalam pengembangan desa wisata jeruk pamelo organik telah dipersepsikan secara baik oleh masyarakat di Desa Tambak Mas.

Disamping itu juga dipersepsikan secara baik dalam pernyataan "Menetapkan Tujuan Jelas dalam Mengelola Desa Wisata" dengan nilai rataan skor sebesar 3,53. Artinya seluruh komponen masyarakat terutama anggota kelompok tani beranggapan bahwa kelompok tani telah memiliki orientasi secara jelas mau dikembangkan seperti apa pengelolaan desa wisata yang direncanakan. Tujuan yang telah ditetapkan merupakan kesepakatan bersama terwujud dari diskusi bersama baik kendala maupun solusi penyelesaiannya. 


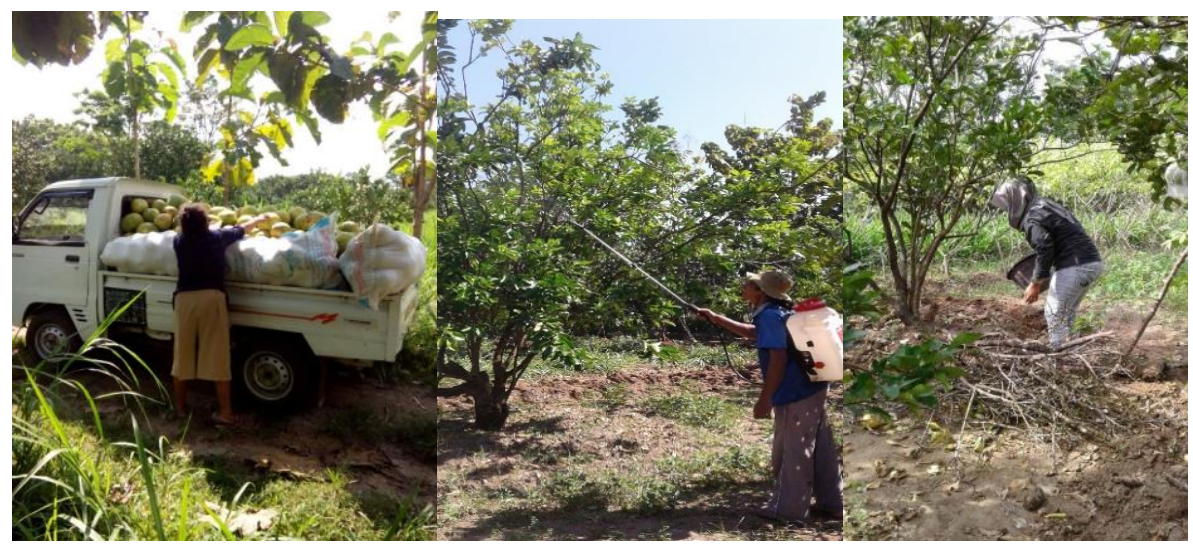

\section{Gambar 2. Beberapa Aktivitas Usahatani Jeruk Pamelo di Desa Tambak Mas} Sumber : Dokumentasi Tim PPMUPT (2019).

\section{b) Dukungan Pemerintah}

Dukungan pemerintah adalah peranan aparatur pemerintah dalam membantu mengurus dan mencukupi kebutuhan masyarakat desa dalam hal pengembangan desa wisata jeruk pamelo organik di Desa Tambakmas, Kecamatan Sukomor, Kabupaten Magetan. Pemerintah yang dimaksud adalah mencakup Pemerintah Desa Tambakmas maupun Pemerintah Kabupaten Magetan beserta dinas-dinas yang relevan terhadap keberlangsungan program. Indikator Dukungan Pemerintah pada Tabel 3. diketahui pernyataan "Aktif Membentuk Kelompok Sadar Wisata (Pokdarwis) memiliki nilai rata-rata skor persepsi tertinggi yaitu sebesar 3.47 , yang artinya pemerintah desa telah berinisitaif membentuk suatu kelompok yang disebut Pokdarwis Tambak Mas guna mendukung pengembangan desa wisata jeruk pamelo organik.

Kelompok ini terdiri dari seluruh elemen masyarakat baik petani, karang taruna, maupun ibu-ibu PKK sehingga diharapkan mampu meningkatkan pendapatan masyarakat, mengurangi pengangguran, menghambat laju urbanisasi sekaligus mencetak entrepreneurentrepreneur mandiri. Dukungan pemerintah dipersepsikan secara buruk melalui kedua pernyataan yaitu "Mendukung Fasilitas Wisata (misal: lahan parkir, petunjuk arah, unit pengelola olahan jeruk pamelo, tempat kuliner dsb)" dan "Menetapkan Anggaran Desa/Kabupaten untuk Desa Wisata" dengan nilai rata-rata skor masing-masing sebesar 1,90 dan 2,10. Hal ini memberikan gambaran bahwa fasilitas wisata berupa lahan parkir, petunjuk arah, unit pengelola olahan jeruk pamelo, tempat kuliner dianggap masih belum ada atau ada tapi belum optimal dijalan sebagaimana mestinya. Lain sisi, kebanyakan dari responden menjawab keberadaan program desa wisata jeruk pamelo organik merupakan program baru yang telah dirintis oleh TIM PPMUPT UPN "Veteran" Jawa Timur dan belum dianggarkan secara khusus baik pembangunan tingkat desa maupun kabupaten, dan pada tahun pertama pelaksanaan program pengabdian adalah bersifat sinkronisasi dengan program yang sudah berjalan. 


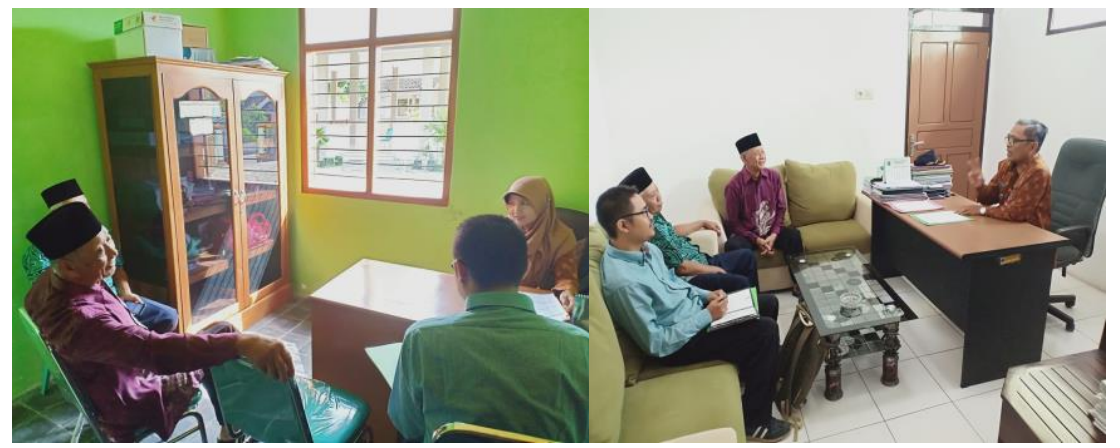

Gambar 3. Koordinasi dan Sosialisasi Program PPMUPT dengan Lurah Desa Tambak Mas (kiri) dan Camat Sukomoro (kanan). Sumber : Dokumentasi Tim PPMUPT (2019).

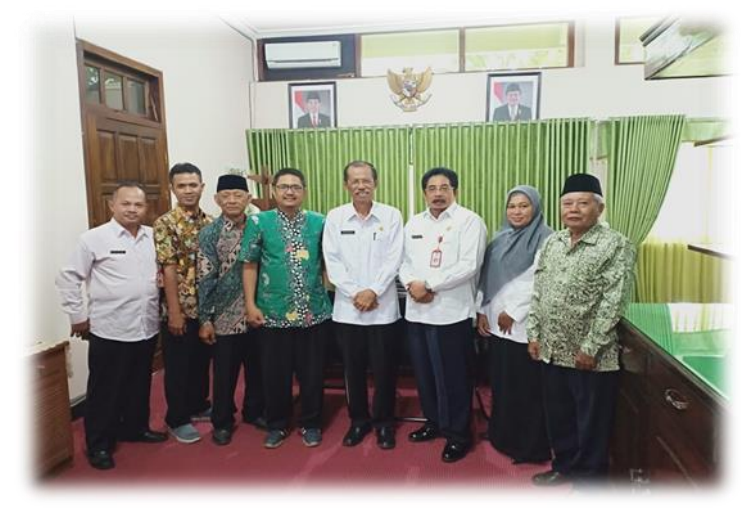

Gambar 4. Sosialisasi dan Permohonan Ijin program PPMUPT kepada Bupati Magetan, disaksikan oleh Sekda, Kepala Dinas Pertanian serta BPMDes dan Gapoktan Desa Tambak Mas.

Sumber : Dokumentasi Tim PPMUPT (2019).

\section{c) Dukungan Tim PPMUPT}

Kategori nilai rata-rata skor pada lima item pernyataan untuk dukungan TIM PPMUPT diketahui > 3,40 yang berarti memiliki persepsi baik. Fakta yang menarik adalah terletak pada pernyataan "Memfasilitasi Pengajuan Sertifikat Organik" menjadi persepsi terbaik yang diberikan oleh responden dengan nilai rata-rata skor 4,00, diikuti oleh pernyataan "Mendampingi Paket Budidaya Jeruk Pamelo Berbasis FOBIO" dengan nilai rata-rata skor sebesar 3.93. Artinya harapan masyarakat Desa Tambak
Mas terhadap pelaksanaan program PPMUPT dan upaya yang telah dilakukan Tim Pengusul mendapat apresiasi luar biasa. Program PPMUPT ini akan bekerjasama dengan Lembaga Sertifikasi Organik LeSOS mulai Bimtek dan Juknis Pertanian Organik sampai memperoleh Sertifikasi Organik.

Disamping itu, Tim Pengusul telah memberikan 250 botol Fobio dan dibuktikan pada Berita Acara Serah Terima Barang (BAST) bersifat wajib diminta oleh DRPM Ristek Dikti sebagai wujud nyata diseminasi teknologi kepada masyarakat. 

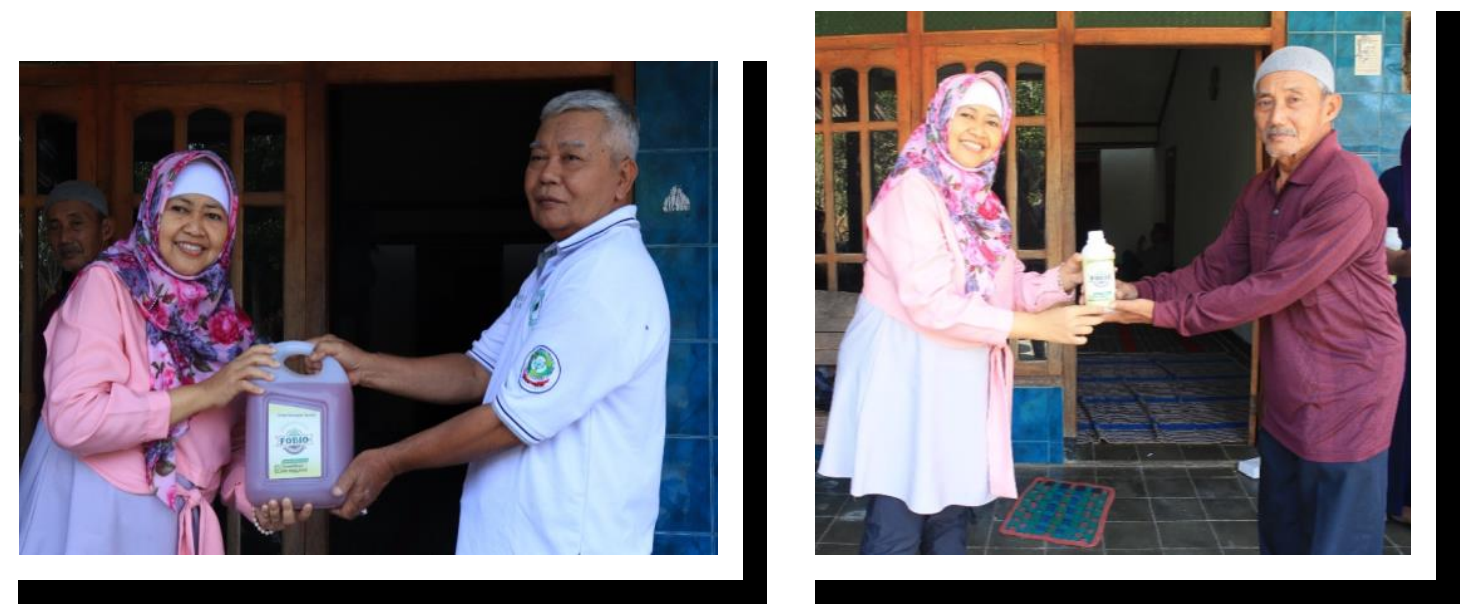

Gambar 5. Penyerahan Formulasi Biopestisida berbasis Mikoorganisme (FOBIO) kepada masing-masing Ketua Kelompok Tani oleh Ketua Tim Pengusul PPMUPT Sumber : Dokumentasi Tim PPMUPT (2019).

\section{UCAPAN TERIMA KASIH}

Tim PPMUPT mengucapkan terima kasih DRPM Ristek Dikti yang memberikan pendanaan dengan Surat Perjanjian Kontrak Nomor: 14/UN 63.8/PM - Kontrak/III/2019 sehingga program yang diusulkan dapat tercapai. Selain itu, pada kesempatan ini juga disampaikan terimakasih kepada LPPM UPN "Veteran" Jatim yang telah menfasilitasi program terkait perijinan dan kerjasama maupun teknologi yang diterapkan dalam program PPMUPT. Tak lupa disampaikan terima kasih kepada Pemerintah Kabupaten Magetan pada umumnya, dan Pemerintah Desa Tambakmas atas segala dukungan yang diberikan serta segenap masyarakat sebagai sasaran program atas segala partisipasinya.

\section{KESIMPULAN}

1. Persepsi internal berhasil terbentuk dari masyarakat yang berpartisipasi dalam pengembangan desa wisata jeruk pamelo organik adalah mereka telah berumur 40 tahun dan atau lebih, berjenjang pendidikan terbanyak adalah SLTA atau sederajat serta memiliki motivasi pokok yaitu meningkatkan pendapatan sambil tetap mempertahankan produktivitas jeruk pamelo yang dibudidayakannya.

2. Eksistensi pengembangan desa wisata jeruk pamelo organik dipersepsikan secara baik pada indikator dukungan kelompok tani dan dukungan Tim PPMUPT. Dukungan kelompok tani

dipersepsikan secara baik melalui pernyataan "Aktif Mengajak Partisipasi Mengelola Desa Wisata" dan "Menjalin Kerjasama dengan Kelompok Masyarakat Lainnya". Indikator Dukungan Tim PPMUPT dipersepsikan baik terutama melalui pernyataan "Memfasilitasi Pengajuan Sertifikat Organik". Sebaliknya, indikator dukungan pemerintah desa dipersepsikan buruk, karena mereka menyatakan "Mendukung Fasilitas Wisata (misal: lahan parkir, petunjuk arah, unit pengelola olahan jeruk pamelo, tempat kuliner dsb)" dan "Menetapkan Anggaran Desa/Kabupaten untuk Desa Wisata" belum sepenuhnya memenuhi harapan masyarakat. 


\section{REFERENSI}

Avenzora R, Teguh F. 2013. Ekowisata dan Pengembangan Pariwisata Berkelanjutan di Indonesia: Potensi, Pembelajaran, dan Kesuksesan, Jakarta (ID): Kementrian Pariwisata dan Ekonomi Kreatif.

BPS, 2018. Hasil Pendataan Potensi Desa (Podes) 2018. https://www.bps.go.id/pressrelease/201 8/12/10/1536/hasil-pendataan-potensidesa--podes--2018.html

BPS Kab. Magetan. 2018. Kecamatan Sukomoro dalam Angka, Kabupaten Magetan.

Charina, Anne, Rani Andriani, Yosini Deliana., 2018. Dampak Penerapan Program Desa Organik Terhadap Petani di Desa Cibodas Kabupaten Bandung Barat. Jurnal Pemikiran Masyarakat Ilmiah Berwawasan Agribisnis. 2018. 4(1): 1-11.

Gao, Jing., Bihu Wu., 2017. Revitalizing traditional villages through rural tourism: A case study of Yuanjia Village, Shaanxi Province, China. Tourism Management 63 (2017) 223233.

Lane, B., \& Kastenholz, E. 2015. Rural tourism: The evolution of practice and research approachesetowards a new generation concept? Journal of Sustainable Tourism, 23(8e9), $1133 \mathrm{e} 1156$.

Mantra, Bagoes Ida. 2009. Demografi Umum. Pustaka Pelajar. Yogyakarta.

Pratt, Stephen., Scott McCabe., Apisalome Movono., 2016. Gross happiness of a 'tourism' village in Fiji. Journal of Destination Marketing \& Management 5 (2016) 26-35.
Rakhmat, Jalaluddin. 1998. Psikologi Komunikasi. Bandung: PT. Remaja Rosdakarya.

Radjabaycolle LR, Sumardjo. 2014. Partisipasi Masyarakat Terhadap Kegiatan Pengelolaan Daerah Aliran Sungai Cikapundung di Kelurahan Dago Bandung. Jurnal Penyuluhan [Vol. 10 No. 1; 43-58. http://journal.ipb.ac.id/index.php/jupe/ article/view/9912/7749

Wang, Y. S., \& Pfister, R. E. 2008. Residents' attitudes toward tourism and perceived personal benefits in a rural community. Journal of Travel Research, 47(1), 84e93.

Williams, J., \& Lawson, R. 2001. Community issues and resident opinions of tourism. Annals of Tourism Research, 28(2), 269e290.

Xu, Honggang., Xingyu Huang., Qianfan Zhang., 2018. Tourism development and local borders in ancient villages in China. Journal of Destination Marketing \& Management 9 (2018) 330-339. 
